medRxiv preprint doi: https://doi.org/10.1101/2020.06.09.20126755; this version posted June 11, 2020. The copyright holder for this preprint (which was not certified by peer review) is the author/funder, who has granted medRxiv a license to display the preprint in perpetuity.

It is made available under a CC-BY-ND 4.0 International license .

\title{
A Diffusion tensor imaging study to compare normative fractional anisotropy values with patients suffering from Parkinson's disease in the brain grey and white matter
}

\author{
Dr. Rahul P Kotian ${ }^{1 *}$, Dr. Prakashini $\mathrm{K}^{2}$, Dr. N Sreekumaran Nair ${ }^{3}$
}

Author ${ }^{1}$ Professor, (PhD), MSc. Medical Imaging Technology, Department of Medical Imaging Technology, College of Allied Health Sciences, Srinivas University, Mukka.

Author ${ }^{2}$ Professor, Department of Radiodiagnosis and Imaging, Kasturba Medical College, MAHE, Manipal. Email id: prakashini.k@ manipal.edu.

Author ${ }^{3}$ Professor, Department of Statistics, MAHE, Manipal. Email id: sreekumaran.nair@manipal.edu.

*Corresponding author: Dr. Rahul P Kotian, Professor, (PhD), MSc. Medical Imaging Technology, Department of Medical Imaging Technology, College of Allied Health Sciences, Srinivas University, Mukka Karnataka, India. E-mail: kotian.rahu18@gmail.com, ORCHID id: orcid.org/0000-0003-2682-158X. SCOPUS id: 56073838900

\begin{abstract}
Background: Diffusion tensor imaging (DTI) appears as a sensitive method to study Parkinson's disease (PD) pathophysiology and severity. Fractional anisotropy (FA) value is one of the scalar derivatives of DTI used to find out anisotropy within a voxel in a tissue and used for determining white matter integrity in aging and neurodegenerative diseases. We studied DTI derived FA in early PD subjects as their routine MRI scans were normal.
\end{abstract}

Methods: 40 patients with early PD and 40 healthy controls were employed to evaluate changes in microstructural white and grey matter in the brain's using DTI derived FA values. Comparison of FA values in the brain's white and grey matter of patients with PD and age matched controls at the corpus callosum, centrum semiovale, pons, putamen, caudate nucleus, substantia nigra, cerebral peduncles and cerebellar peduncles, was done using a region of interest (ROI) technique, with b-value $1000 \mathrm{~s} / \mathrm{mm}^{2}$ and $\mathrm{TE}=100$ milliseconds using $1.5 \mathrm{~T}$ MRI system.

Results: PD patients showed differences in FA values in both the grey and white matter areas of the brain's compared to healthy controls. Our study revealed the presence of damage in the substantia nigra, corpus callosum, putamen and cerebral peduncles mainly in the PD group. 
medRxiv preprint doi: https://doi.org/10.1101/2020.06.09.20126755; this version posted June 11, 2020. The copyright holder for this preprint (which was not certified by peer review) is the author/funder, who has granted medRxiv a license to display the preprint in perpetuity.

It is made available under a CC-BY-ND 4.0 International license .

Conclusion: Our findings indicate that DTI and region of interest (ROI) methods can be used in patients with early PD to study microstructural alterations mainly in the substantia nigra, putamen and corpus callosum.

Keywords: Fractional anisotropy, diffusion tensor imaging, Parkinson's disease, magnetic resonance imaging, neuroimaging.

\section{'Declarations'}

- Ethics approval and consent to participate - The study protocol followed was reviewed and approved by the Research Committee of Manipal College of Health Profession and Manipal Academy of Higher Education, and ethical clearance was also obtained by Kasturba Medical College and Hospital, MAHE, Manipal. A detailed explanation about the study was given by the principal investigator after which they provided consent for publication. All the patients included in this research gave written informed consent to publish the data contained within this study.

- Compliance with ethical standards- All ethical standards were maintained.

- Ethics reference number- IEC 407/2014

- Availability of data and material- The data collected in the current study comprises of screenshot images taken after obtaining FA values of PD patients and healthy controls using diffusion tensor imaging fibre track software. The data will be shared on request as per the Kasturba Medical hospital ethical committee patient privacy guidelines. The datasets used and/or analysed during the current study is available from the corresponding author on reasonable request.

- Competing interests- The authors declare that they have no competing interests in this study.

- Funding- Bombay Scientific, Mumbai, Maharashtra, India.

- Authors' contributions- RK conceptualized the study. RK, PK and SN have given inputs in study design. RK collected the data. RK analysed the data and wrote the first draft of manuscript and all co- authors contributed in critical review of data analysis and manuscript writing. RK will act as guarantor for this paper. All authors have read and approved the manuscript.

- Acknowledgements- Not applicable 
medRxiv preprint doi: https://doi.org/10.1101/2020.06.09.20126755; this version posted June 11, 2020. The copyright holder for this preprint

\section{Introduction}

Parkinson's disease (PD) is a dopamine related dysfunction and its diagnosis is made in the presence of at least one motor systems, such as, bradykinesia, rest tremor, rigidity and postural instability [1]. PD manifests within the brain very slowly and hence conventional MRI scans fail to pick any significant changes. However, MRI brain scans can show age related and atrophy changes but the overall diagnostic value in PD is poor. Early diagnosis in PD allows the clinicians to improve the quality of life and reduce morbidity of these PD patients.

The search of a neuroimaging biomarker for early PD diagnosis is crucial and might have a high impact on a patient's quality of life. Diffusion tensor imaging (DTI) is a beneficial tool to assess white and grey matter abnormalities, which can be used in the longterm assessment of the patients and serve as the imaging markers of disease progression and treatment response $[2,3]$. The measures obtained from DTI are fractional anisotropy (FA), mean diffusivity (MD), radial diffusivity (RD) and axial diffusivity (AD). FA quantifies the preferred diffusion direction of water molecules through white matter tracts, and MD represents diffusion magnitude $[4,5]$. FA is one of the most commonly used quantitative measure of diffusion in the brain in PD cases. The recent trend in using DTI as a diagnostic tool in PD has generated importance on our understanding of structural abnormalities of this disease and the robust technique for PD imaging has been the use of FA [6].

Previous studies in DTI still lack vital information about alteration beyond the substantia nigra (SN), according to a meta-analysis related degeneration in PD [7]. Recently, DTI has been proved to be useful in PD detection in both grey and white matter regions of the brain [8,9]. Some studies also focused on subcortical, cortical, white matter, cerebellar regions, and reported significant alterations in PD in many regions including the substantia nigra, caudate nucleus, putamen, globus pallidus, olfactory cortex and white matter of the corpus callosum [10]. Putaminal diffusivity correlates with disease progression in Parkinson's Disease which shows involvement in brain grey matter [11].

Changes in FA values has been reported in numerous cases on PD, but its clinical use in diagnosis and treatment remains challenging and has not been adopted till now [12-16]. Tract based spatial statistics (TBSS) studies published till date reported a higher rate of false negatives and do not suggest a definite diagnosis and correlation [17]. Inclusion of small set of ROIs' in studies reported on PD in both grey and white matter have led to unclear findings about FA on PD [18]. 
medRxiv preprint doi: https://doi.org/10.1101/2020.06.09.20126755; this version posted June 11, 2020. The copyright holder for this preprint

The main purpose of this study was to investigate the role of DTI imaging in different grey and white matter regions of the brain using FA values with ROI technique involved in early PD among those of healthy controls. We considered freehand ROI, as a unique technique for calculating FA at the grey and white regions of the brain because we were able to select the exact size, location and position of the desired anatomy to be evaluated unlike TBSS techniques.

\section{Methods}

The study protocol followed was reviewed and approved by the Research Committee of Manipal College of Health Profession and Manipal Academy of Higher Education, and ethical clearance was also obtained by Kasturba Medical College and Hospital, Manipal Academy of Higher Education, Manipal. A detailed explanation about the study was given by the principal investigator after which they provided consent for publication. All the patients included in this research gave written informed consent to publish the data contained within this study.

\subsection{Subjects}

This was a case-control study with a prospective design. A total of 40 patients with PD aged 53-75 years (25 males, 15 females, mean age: $64.05 \pm 8.79$ years); and healthy control subjects (25 males, 15 females, mean age: $65.05 \pm 8.37$ years) were enrolled. The duration of the disease was < 1 years in 25 cases and 1-3 years in 15 cases. All patients met the UK PD Society Brain Bank Clinical Diagnostic Criteria for probable PD. The Unified Parkinson Disease Rating scale (UPDRS) was also taken into consideration.

All the controls underwent a rigorous screening for neurological abnormalities including a routine MR brain imaging. Patients with clinically diagnosed parkinsonian syndromes i.e. early PD (0-3 years), were included in the study in the age group of 40-75 years. Patients suffering from vascular parkinsonism, multiple system atrophy (MSA) with (PD), PD dementia (PDD), or Lewy body dementia were excluded from the study. They were also excluded in the presence of the following criteria: 1) presence of structural brain abnormalities, 2) history of intracranial surgery or 3) major physical or neuropsychiatric disorders. Subjects with mild atrophy were considered eligible for the study. 
medRxiv preprint doi: https://doi.org/10.1101/2020.06.09.20126755; this version posted June 11, 2020. The copyright holder for this preprint (which was not certified by peer review) is the author/funder, who has granted medRxiv a license to display the preprint in perpetuity.

It is made available under a CC-BY-ND 4.0 International license .

\subsection{Image Acquisition}

Images were acquired on a 1.5-Tesla Philips Achieva, class IIA series using a 16 channel head coil system. Conventional imaging (T2- weighted FLAIR axial and T1weighted sagittal sequences) was performed to rule out neurological abnormalities. DTI images were acquired using a single shot echo-planar imaging (EPI) sequence with the following parameters: $b$-value $=1000, \mathrm{TR} / \mathrm{TE} /$ slice thickness $=8648 \mathrm{~ms} / 100 \mathrm{~ms} / 2 \mathrm{~mm}$, matrix size $=112 \times 110$, and FOV $=224 \times 224 \mathrm{~mm}$. Parallel imaging was used, with an acceleration factor of two and generalized auto calibrating partially parallel acquisition (GRAPPA) reconstruction and EPI factor of 55. Diffusion-weighting gradients were applied in 15 noncollinear directions.

\subsection{DTI derived measures from ROIs}

A ROI technique was used to estimate FA values. The following ROIs were included in our analyses: corpus callosum, centrum semiovale, pons, substantia nigra, thalamus, cerebral peduncles, cerebellar peduncles, caudate nucleus and putamen. We used a voxel size of eight for corpus callosum, centrum semiovale and pons, a 4 voxel ROI at the cerebellar peduncles; while a single voxel was used to measure ROI's in the rest of the regions as depicted in Fig. 1 - 6 .

\subsection{Image Analysis \& Post-processing}

ROI identification and estimation of FA values were done using the Philips extended workspace. The DTI image sets were loaded along with sequence Flair axial and T1 Sagittal for anatomy correlation to visualize and calculate FA values. ROI's using standard techniques and anatomy reference overlap sequences were drawn in the brain regions mentioned above using DTI Philips extended MR fiber track software version 7.1.5.1.

\subsection{Statistical Analysis}

All analyses were performed using the SPSS software package (version 16.0). The independent sample t-test was used to compare the difference in FA values between PD patients and healthy controls for each of the ROIs studied. To determine imaging biomarkers for early PD diagnosis, we generated receiver-operating characteristics (ROC) analysis to identify and predict early PD. P-values less than 0.05 was considered statistically significant. 


\section{Results}

\subsection{Demographic Characteristics of Participants}

Demographic and clinical data are depicted in Table 1.

\subsection{Diagnostic performance of diffusion tensor imaging}

Mean FA values of the brain white and grey matter regions are summarized in Table 2. The highest FA values were in the splenium of the corpus callosum close to 0.70 and the lowest FA values about 0.40 in the caudate nucleus in the PD group compared to control group which showed the highest and lowest FA values of 0.69 at the splenium of the corpus callosum and 0.45 at the caudate nucleus respectively.

\subsection{Independent sample t-test between PD and control group}

We found statistically significant difference between the PD and control group $(P<$ 0.05) in the following regions of the brain: Genu and body of corpus callosum, pons, putamen, substantia nigra and cerebral peduncles as depicted in Table. 3.

\subsection{Receiver operator characteristics curves}

ROC analysis was done for the regions of the brain which showed statistically significant difference namely the genu and body of the corpus callosum, pons, substantia nigra, putamen and cerebral peduncles to find out positive predictors in PD group compared to controls as shown in Table. 4. The area under the ROC curve (AUC) is a measure of how well a parameter can distinguish between two diagnostic groups (diseased/controls). A rough guide for classifying the accuracy of a diagnostic test is the traditional academic point system: .90-1 $=$ excellent $(\mathrm{A}) .80-.90=\operatorname{good}(\mathrm{B}) .70-.80=$ fair $(\mathrm{C}) .60-.70=$ poor $(\mathrm{D})$. 
medRxiv preprint doi: https://doi.org/10.1101/2020.06.09.20126755; this version posted June 11, 2020. The copyright holder for this preprint (which was not certified by peer review) is the author/funder, who has granted medRxiv a license to display the preprint in perpetuity.

It is made available under a CC-BY-ND 4.0 International license.

Table 1. Demographic and clinical data of subjects

\begin{tabular}{lccc}
\hline $\mathrm{N}=40$ & PD & Controls & p value \\
\hline Age in years & $64.05 \pm 8.79$ & $65.05 \pm 8.37$ & 0.456 \\
Sex $(\mathrm{M} / \mathrm{F})$ & $25: 15$ & $25: 15$ & 0.376 \\
$\begin{array}{l}\text { Disease duration } \\
\text { (Months) }\end{array}$ & $10 \pm 2.25$ & $\mathrm{NA}$ & $\mathrm{NA}$ \\
\hline
\end{tabular}

No difference $(\mathrm{p}>0.05)$ in age between each group.

NA- not applicable

Table 2. Mean and standard deviation of FA values in PD and control group

\begin{tabular}{|c|c|c|c|}
\hline $\begin{array}{l}\text { Sr. } \\
\text { No }\end{array}$ & Regions of the brain & $\begin{array}{l}\text { FA @ Controls } \\
(\text { Mean } \pm \text { SD) }\end{array}$ & $\begin{array}{c}\text { FA@PD } \\
(\text { Mean } \pm \mathrm{SD})\end{array}$ \\
\hline 1 & Genu of corpus callosum & $0.559 \pm 0.86$ & $0.660 \pm 0.07$ \\
\hline 2 & Body of corpus callosum & $0.566 \pm 0.11$ & $0.626 \pm 0.11$ \\
\hline 3 & $\begin{array}{l}\text { Splenium of corpus } \\
\text { callosum }\end{array}$ & $0.693 \pm 0.13$ & $0.700 \pm 0.06$ \\
\hline 4 & Centrum Semiovale & $0.529 \pm 0.06$ & $0.557 \pm 0.06$ \\
\hline 5 & Pons & $0.586 \pm 0.04$ & $0.608 \pm 0.05$ \\
\hline 6 & Caudate Nucleus & $0.454 \pm 0.14$ & $0.409 \pm 0.09$ \\
\hline 7 & Putamen & $0.530 \pm 0.07$ & $0.469 \pm 0.08$ \\
\hline 8 & Thalamus & $0.508 \pm 0.07$ & $0.514 \pm 0.08$ \\
\hline 9 & Substantia nigra & $0.607 \pm 0.07$ & $0.422 \pm 0.01$ \\
\hline 10 & Cerebral peduncles & $0.614 \pm 0.05$ & $0.645 \pm 0.11$ \\
\hline 11 & Cerebellar peduncles & $0.508 \pm 0.11$ & $0.567 \pm 0.09$ \\
\hline
\end{tabular}


medRxiv preprint doi: https://doi.org/10.1101/2020.06.09.20126755; this version posted June 11, 2020. The copyright holder for this preprint (which was not certified by peer review) is the author/funder, who has granted medRxiv a license to display the preprint in perpetuity.

It is made available under a CC-BY-ND 4.0 International license .

Table 3. Independent sample t test between PD and control group at the white and grey matter regions of the brain

\begin{tabular}{ccc} 
Sr. No & Regions of the brain & p value (FA value comp \\
& & PD and Contro \\
1 & Genu of corpus callosum & $0.000^{*}$ \\
3 & Body of corpus callosum & $0.016^{*}$ \\
4 & Splenium of corpus callosum & 0.755 \\
5 & Centrum Semiovale & 0.082 \\
6 & Pons & $0.037^{*}$ \\
7 & Caudate Nucleus & 0.165 \\
8 & Putamen & $0.000^{*}$ \\
9 & Thalamus & 0.214 \\
10 & Substantia nigra & $0.000^{*}$ \\
11 & Cerebral peduncles & $0.003^{*}$ \\
\hline & Cerebellar peduncles & 0.409
\end{tabular}

*- signifies statistically significant data

Table 4. ROC curve analysis

\begin{tabular}{ccccc}
\hline Predictors & Area under the curve & Cut-off & Sensitivity & Specificity \\
\hline Genu of corpus callosum & 0.836 & 0.6075 & 0.8 & 0.85 \\
Body of corpus callosum & 0.688 & 0.5545 & 0.8 & 0.625 \\
Pons & 0.630 & 0.586 & 0.575 & 0.475 \\
Putamen & 0.741 & 0.498 & 0.750 & 0.725 \\
Substantia Nigra & 1.0 & 0.484 & 1.000 & 1.000 \\
Cerebral Peduncles & 0.741 & 0.719 & 0.75 & 0.70 \\
\hline
\end{tabular}


medRxiv preprint doi: https://doi.org/10.1101/2020.06.09.20126755; this version posted June 11, 2020. The copyright holder for this preprint (which was not certified by peer review) is the author/funder, who has granted medRxiv a license to display the preprint in perpetuity.

It is made available under a CC-BY-ND 4.0 International license .

\section{Discussion}

\subsection{Substantia nigra and FA values}

ROI analysis showed FA values in the substantia nigra were statistically significant and lower in the PD group compared to the control group. Reduced FA values in the substantia nigra of PD patients are a direct effect of loss of neurons. This justifies that the PD group had grey matter alterations which is in line with a systematic review conducted in 2013 and other studies conducted worldwide [19-21]. Our results showed that the FA values in the substantia were reduced in PD patients, suggesting that damage to this structure is directly related to changes in PD consistent with previous studies [22-27]. It has been postulated that damage to the brain results in axonal loss which in turn is associated with changes in FA values.

\subsection{Putamen and FA values}

Lower FA values at the putamen obtained in the study may be used in early prediction of PD. A similar study also quoted the importance of putaminal diffusivity with disease progression in PD with increase in FA values and involvement of the brain grey matter [28]. So, in early PD putamen FA values tend to be on the lower side as stated in the current study findings but as the disease progresses, FA values may tend to increase. Iron deposition in the substantia nigra is observed in PD cases, where iron levels increases FA values at the putamen. This should also be taken into consideration while interpreting FA at the putamen in the clinical set up [29-31].

\subsection{Corpus callosum and FA values}

We found statistically significant difference with higher FA in the PD group compared to the control group in the genu and body of the corpus callosum. Generally notable volume loss occurs in the corpus callosum in late stages of PD. Findings of higher FA at the corpus callosum in PD group compared to controls might be a classical feature seen only in early PD cases. Hence, the findings of increased FA in the genu and body of the corpus callosum sounds noteworthy and can be utilized for diagnosis in early PD cases which is a noble finding and not yet reported in literature. As the disease progresses in PD, dementia, lewy body appearance and Alzheimer's disease come into play which in turn may cause FA value to reduce as the total volume of the corpus callosum will decrease $[32,33]$. This trend in corpus callosum has to be sensitively monitored while differentiating early and 
medRxiv preprint doi: https://doi.org/10.1101/2020.06.09.20126755; this version posted June 11, 2020. The copyright holder for this preprint (which was not certified by peer review) is the author/funder, who has granted medRxiv a license to display the preprint in perpetuity.

It is made available under a CC-BY-ND 4.0 International license .

late PD cases. In general anisotropy depends on the structural arrangement of neurons, compactness and inter-neuronal space. A new advent of a disease, causing disturbance to its normal structure might cause a momentary rise in FA at the corpus callosum but as the disease progresses FA values will tend to fall and be on the lower side.

\subsection{Cerebral peduncles and FA values}

Limited and sporadic studies have been conducted to find the association of cerebral peduncles and FA values and none of them have found any significant results to use cerebral peduncle as a biomarker to predict early PD [34,35]. Some studies have used FA at the cerebral peduncle as a baseline for comparison with disease group. Hence, further studies with larger sample size has to be conducted to evaluate the effectiveness of using cerebral peduncle as a biomarker for detecting early PD.

\subsection{Pons and FA values}

FA in the pons showed statistically significant difference with higher FA in the PD group compared to control group using independent sample ' $t$ ' test. But roc curve analysis low sensitivity and specificity and hence, did not reveal any positive correlation between PD and control group. Hence, the usefulness of pons as an imaging biomarker remains unclear by the present study findings.

\section{Conclusion}

In early stage parkinsonism, genu and body of the corpus callosum, and cerebral peduncles showed higher FA while lower FA values were seen in the putamen and substantia nigra as compared to healthy controls. Using a ROI approach, FA measures of the substantia nigra seems to be the most appropriate biomarker for differentiating early PD from healthy controls. We consider FA at the putamen as an early predictor of PD. Corpus callosum can be utilized for diagnosis in early PD cases which is a noble finding and not yet reported in literature.

\section{Compliance with ethical standard}

Conflict of interest: The authors declare that they have no competing interests in this study.

Ethical approval: The study protocol followed was reviewed and approved by the Research Committee of Manipal College of Health Profession and Manipal Academy of Higher 
medRxiv preprint doi: https://doi.org/10.1101/2020.06.09.20126755; this version posted June 11, 2020. The copyright holder for this preprint (which was not certified by peer review) is the author/funder, who has granted medRxiv a license to display the preprint in perpetuity.

It is made available under a CC-BY-ND 4.0 International license .

Education, and ethical clearance was also obtained by Kasturba Medical College and Hospital, MAHE, Manipal

Informed consent: A detailed explanation about the study was given by the principal investigator after which they provided consent for publication. All the patients included in this research gave written informed consent to publish the data contained within this study.

\section{References}

1. Daniel SE, Lees AJ. Parkinson's Disease Society Brain Bank, London: overview and research. Journal of neural transmission. Supplementum. 1993;39:165.

2. Gattellaro G, Minati L, Grisoli M, Mariani C, Carella F, Osio M, Ciceri E, Albanese A, Bruzzone MG. White matter involvement in idiopathic Parkinson disease: a diffusion tensor imaging study. American Journal of Neuroradiology. 2009 Jun 1;30(6):1222-6.

3. Skidmore FM, Yang M, Baxter L, Von Deneen KM, Collingwood J, He G, White K, Korenkevych D, Savenkov A, Heilman KM, Gold M. Reliability analysis of the resting state can sensitively and specifically identify the presence of Parkinson disease. Neuroimage. 2013 Jul 15;75:249-61.

4. Mori S, Zhang J. Principles of diffusion tensor imaging and its applications to basic neuroscience research. Neuron. 2006 Sep 7;51(5):527-39.

5. Alexander AL, Lee JE, Lazar M, Field AS. Diffusion tensor imaging of the brain. Neurotherapeutics. 2007 Jul 1;4(3):316-29.

6. Zhang K, Yu C, Zhang Y, Wu X, Zhu C. Voxel-based analysis of diffusion tensor indices in the brain in patients with Parkinson' s disease. Eur J Radiol [Internet]. 2017;77(2):269-73.

7. Saeed U, Compagnone J, Aviv RI, Strafella AP, Black SE, Lang AE, Masellis M. Imaging biomarkers in Parkinson's disease and Parkinsonian syndromes: current and emerging concepts. Translational neurodegeneration. 2017 Dec;6(1):8.

8. Cochrane CJ, Ebmeier KP. Diffusion tensor imaging in parkinsonian syndromes: a systematic review and meta-analysis. Neurology. 2013 Feb 26;80(9):857-64. 
medRxiv preprint doi: https://doi.org/10.1101/2020.06.09.20126755; this version posted June 11, 2020. The copyright holder for this preprint (which was not certified by peer review) is the author/funder, who has granted medRxiv a license to display the preprint in perpetuity.

It is made available under a CC-BY-ND 4.0 International license .

9. Schwarz ST, Abaei M, Gontu V, Morgan PS, Bajaj N, Auer DP. Diffusion tensor imaging of nigral degeneration in Parkinson's disease: a region-of-interest and voxelbased study at $3 \mathrm{~T}$ and systematic review with meta-analysis. NeuroImage: Clinical. 2013 Jan 1;3:481-8.

10. Atkinson-Clement C, Pinto S, Eusebio A, Coulon O. Diffusion tensor imaging in Parkinson's disease: Review and meta-analysis. NeuroImage: Clinical. 2017 Jan $1 ; 16: 98-110$.

11. Chan LL, Ng KM, Yeoh CS, Rumpel H, Li HH, Tan EK. Putaminal Diffusivity Correlates With Disease Progression in Parkinson's Disease: Prospective 6-Year Study. Medicine. 2016 Feb;95(6).

12. Zhan W, Kang GA, Glass GA, Zhang Y, Shirley C, Millin R, et al. Regional alterations of brain microstructure in Parkinson's disease using diffusion tensor imaging. Mov Disord. 2012;27(1):90-7.

13. Langley J, Huddleston DE, Merritt M, Chen X, McMurray R, Silver M, et al. Diffusion tensor imaging of the substantia nigra in Parkinson's disease revisited. Hum Brain Mapp. 2016;37(7):2547-56.

14. Duncan GW, Firbank MJ, Yarnall AJ, Khoo TK, Brooks DJ, Barker RA, et al. Gray and white matter imaging: A biomarker for cognitive impairment in early Parkinson's disease? Mov Disord. 2016;31(1):103-10.

15. Chen N-K, Chou Y, Sundman M, Hickey P, Kasoff WS, Bernstein A, et al. Alteration of diffusion-tensor MRI measures in brain regions involved in early stages of Parkinson's disease. Brain Connect. 2018; brain.2017.0558.

16. Gattellaro G, Minati L, Grisoli M, Mariani C, Carella F, Osio M, et al. White matter involvement in idiopathic Parkinson disease: A diffusion tensor imaging study. Am $\mathrm{J}$ Neuroradiol. 2009;30(6):1222-6.

17. Rolheiser TM, Fulton HG, Good KP, Fisk JD, McKelvey JR, Scherfler C, et al. Diffusion tensor imaging and olfactory identification testing in early-stage Parkinson's disease. J Neurol. 2011;258(7):1254-60.

18. Joshi N, Rolheiser TM, Fisk JD, McKelvey JR, Schoffer K, Phillips G, et al. Lateralized microstructural changes in early-stage Parkinson's disease in anterior olfactory structures, but not in substantia nigra. J Neurol. 2017;264(7):1497-505.

19. Schwarz ST, Abaei M, Gontu V, Morgan PS, Bajaj N, Auer DP. Diffusion tensor imaging of nigral degeneration in Parkinson's disease: A region-of-interest and voxel- 
medRxiv preprint doi: https://doi.org/10.1101/2020.06.09.20126755; this version posted June 11, 2020. The copyright holder for this preprint (which was not certified by peer review) is the author/funder, who has granted medRxiv a license to display the preprint in perpetuity.

It is made available under a CC-BY-ND 4.0 International license .

based study at $3 \mathrm{~T}$ and systematic review with meta-analysis. NeuroImage Clin. 2013;3:481-8.

20. Melzer TR, Watts R, Macaskill MR, Pitcher TL, Livingston L, Keenan RJ, et al. White matter microstructure deteriorates across cognitive stages in Parkinson disease. Neurology. 2013;80(20):1841-9.

21. Pozorski V, Oh JM, Adluru N, Merluzzi AP, Theisen F, Okonkwo O, et al. Longitudinal white matter microstructural change in Parkinson's disease. 2018:1-12.

22. Prakash BD, Sitoh Y-Y, Tan LCS, Au WL. Asymmetrical diffusion tensor imaging indices of the rostral substantia nigra in Parkinson's disease. Parkinsonism Relat Disord. 2012 Nov;18(9):1029-33.

23. Cochrane CJ, Ebmeier KP. Diffusion tensor imaging in parkinsonian syndromes: A systematic review and meta-analysis. Neurology. 2013;80(9):857-64.

24. Zhang Y, Wu IW, Tosun D, Foster E, Schuff N. Progression of regional microstructural degeneration in Parkinson's disease: A multicenter diffusion tensor imaging study. PLoS One. 2016;11(10):1-16.

25. Vaillancourt DE, Spraker MB, Prodoehl J, Abraham I, Corcos DM, Zhou XJ, et al. High-resolution diffusion tensor imaging in the substantia nigra of de novo Parkinson disease. Neurology 2009 Apr 21;72(16):1378-84.

26. Péran P, Cherubini A, Assogna F, Piras F, Quattrocchi C, Peppe A, et al. Magnetic resonance imaging markers of Parkinson's disease nigrostriatal signature. Brain. 2010 Nov;133(11):3423-33.

27. Chan L-L, Rumpel H, Yap K, Lee E, Loo H-V, Ho G-L, et al. Case control study of diffusion tensor imaging in Parkinson's disease. J Neurol Neurosurg Psychiatry. 2007 Dec 1;78(12):1383-6.

28. Chan LL, Ng KM, Yeoh CS, Rumpel H, Li HH, Tan EK. Putaminal Diffusivity Correlates with Disease Progression in Parkinson's Disease. Med (United States). 2016;95(6):1-4.

29. Rulseh AM, Keller J, Tintěra J, Kožíšek M, Vymazal J. Chasing shadows: what determines DTI metrics in gray matter regions? An in vitro and in vivo study. J Magn Reson Imaging. 2013 Nov;38(5):1103-10.

30. Pfefferbaum A, Adalsteinsson E, Rohlfing T, Sullivan E V. Diffusion tensor imaging of deep gray matter brain structures: effects of age and iron concentration. Neurobiol Aging. 2010 Mar;31(3):482-93. 
medRxiv preprint doi: https://doi.org/10.1101/2020.06.09.20126755; this version posted June 11, 2020. The copyright holder for this preprint (which was not certified by peer review) is the author/funder, who has granted medRxiv a license to display the preprint in perpetuity.

It is made available under a CC-BY-ND 4.0 International license .

31. White ML, Zhang Y. Three-tesla diffusion tensor imaging of Meyer's loop by tractography, color-coded fractional anisotropy maps, and eigenvectors. Clin Imaging. 2010 Jan;34(6):413-7.

32. Goldman JG, Bledsoe IO, Merkitch D, Dinh V, Bernard B, Stebbins GT. Corpus callosal atrophy and associations with cognitive impairment in Parkinson disease. Neurology. 2017 Mar 28;88(13):1265-72.

33. Wiltshire K, Foster S, Kaye JA, Small BJ, Camicioli R. Corpus Callosum in Neurodegenerative Diseases: Findings in Parkinson's Disease. Dement Geriatr Cogn Disord. 2005;20(6):345-51.

34. Meijer FJA, Rumund A Van, Tuladhar AM. Conventional 3T brain MRI and diffusion tensor imaging in the diagnostic workup of early stage parkinsonism. Neuroradiology. 2015;655-69.

35. Meijer FJA, Bloem BR, Mahlknecht P, Seppi K, Goraj B. Update on diffusion MRI in Parkinson's disease and atypical parkinsonism. J Neurol Sci. 2013;332(1-2):21-9.

Figures Legends:

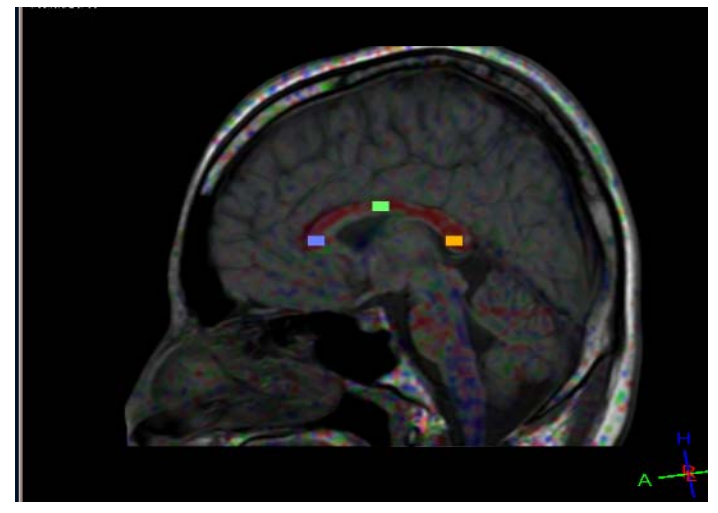

Fig. 1. ROI at Corpus callosum- (genu, body and splenium

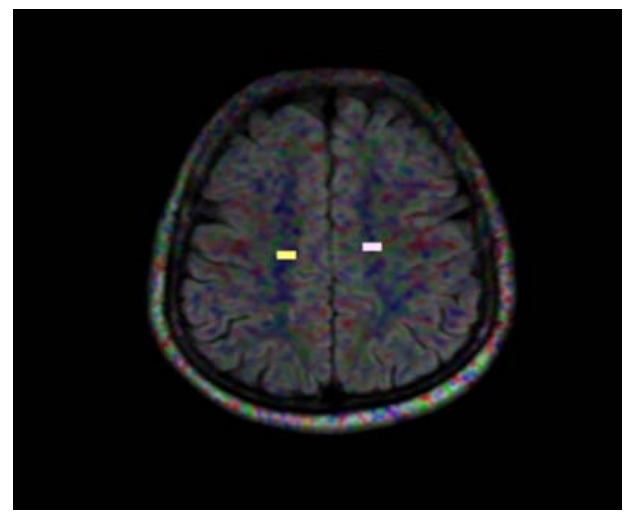

Fig. 2. ROI at centrum semiovale (Right and Left) 
medRxiv preprint doi: https://doi.org/10.1101/2020.06.09.20126755; this version posted June 11, 2020. The copyright holder for this preprint (which was not certified by peer review) is the author/funder, who has granted medRxiv a license to display the preprint in perpetuity.

It is made available under a CC-BY-ND 4.0 International license .

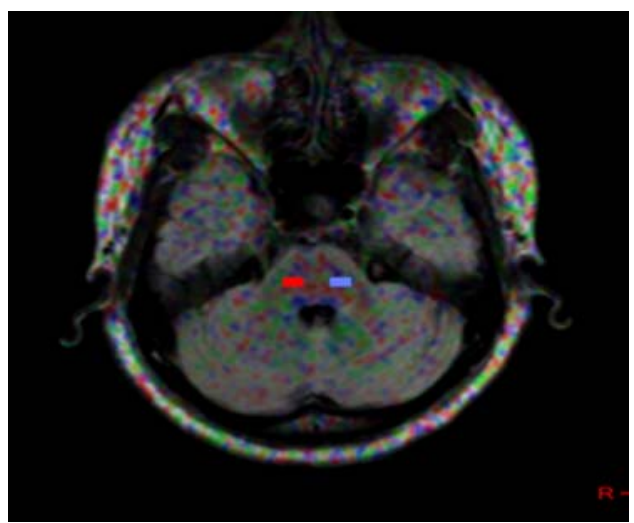

Fig. 3. ROI at Pons- (Right and Left)

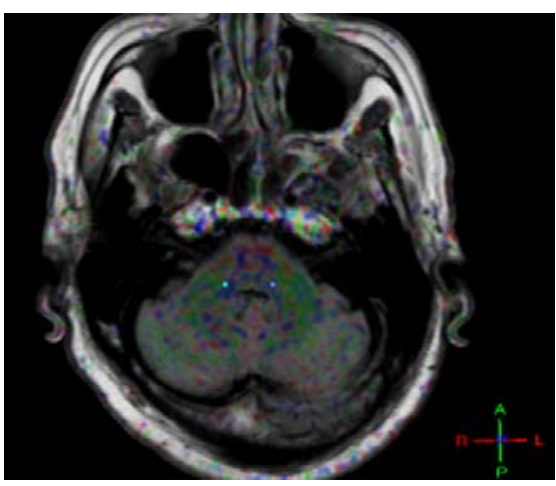

Fig. 5. ROI at Cerebellar Peduncles (Right \& Left)

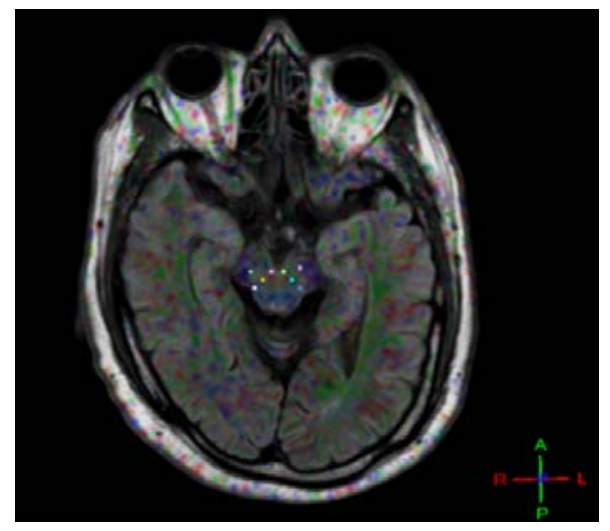

Fig. 4. ROI at Substantia nigra (Right \& Left)

And Cerebral Peduncles (Right \& Left)

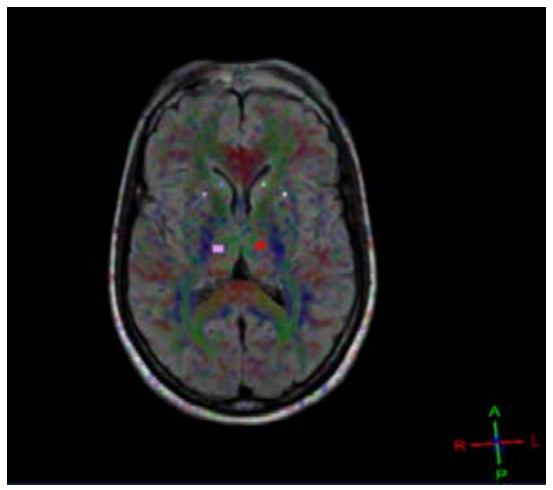

Fig. 6. ROI at Caudate Nucleus (Right \& Left),

Putamen (Right \& Left),

Thalamus (Right \& Left) 
medRxiv preprint doi: https://doi.org/10.1101/2020.06.09.20126755; this version posted June 11, 2020. The copyright holder for this preprint (which was not certified by peer review) is the author/funder, who has granted medRxiv a license to display the preprint in perpetuity. It is made available under a CC-BY-ND 4.0 International license.

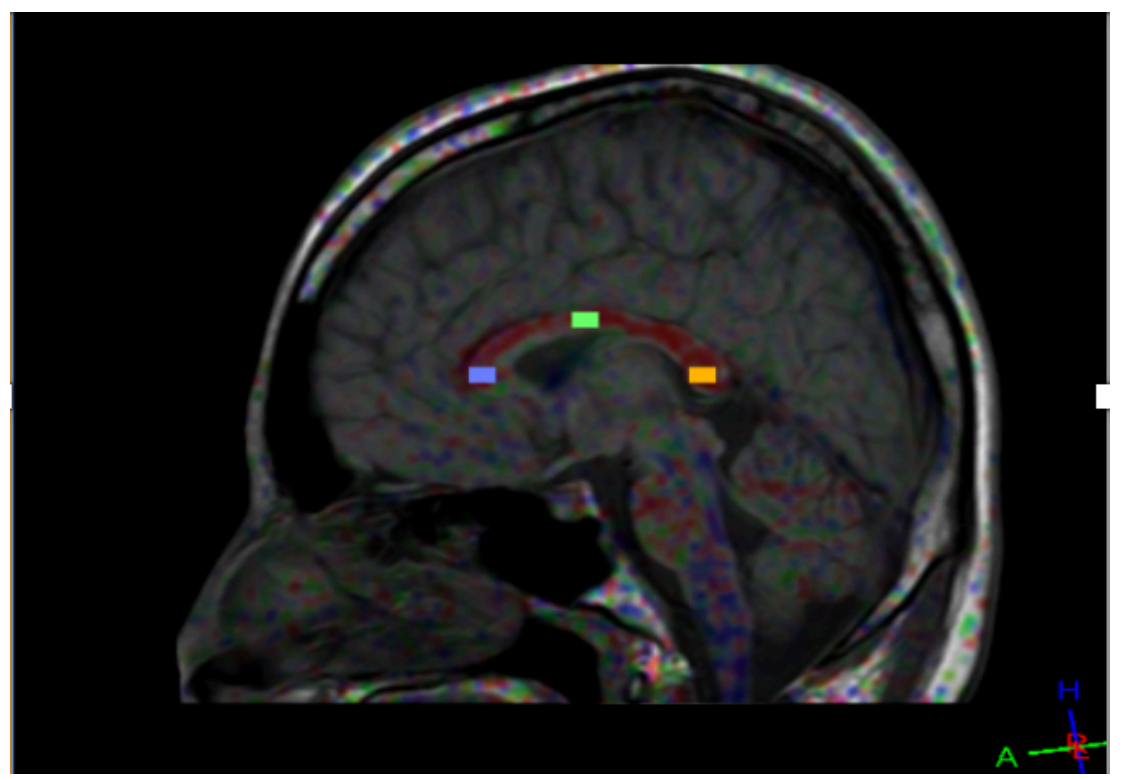


medRxiv preprint doi: https://doi.org/10.1101/2020.06.09.20126755; this version posted June 11, 2020. The copyright holder for this preprint (which was not certified by peer review) is the author/funder, who has granted medRxiv a license to display the preprint in perpetuity. It is made available under a CC-BY-ND 4.0 International license.

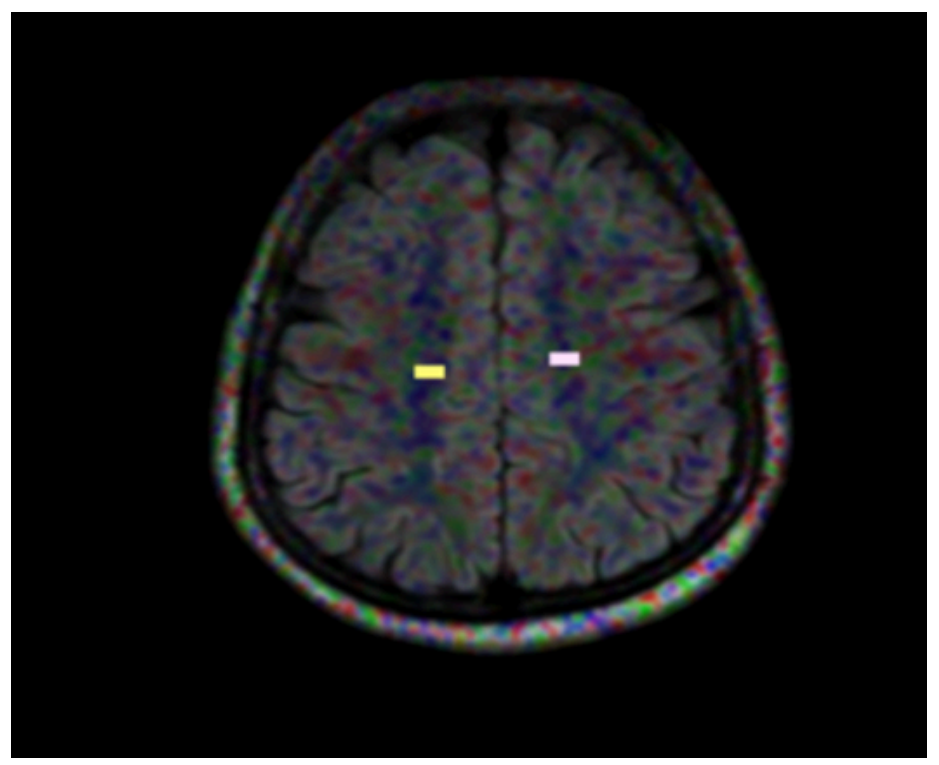


medRxiv preprint doi: https://doi.org/10.1101/2020.06.09.20126755; this version posted June 11, 2020. The copyright holder for this preprint (which was not certified by peer review) is the author/funder, who has granted medRxiv a license to display the preprint in perpetuity. It is made available under a CC-BY-ND 4.0 International license.

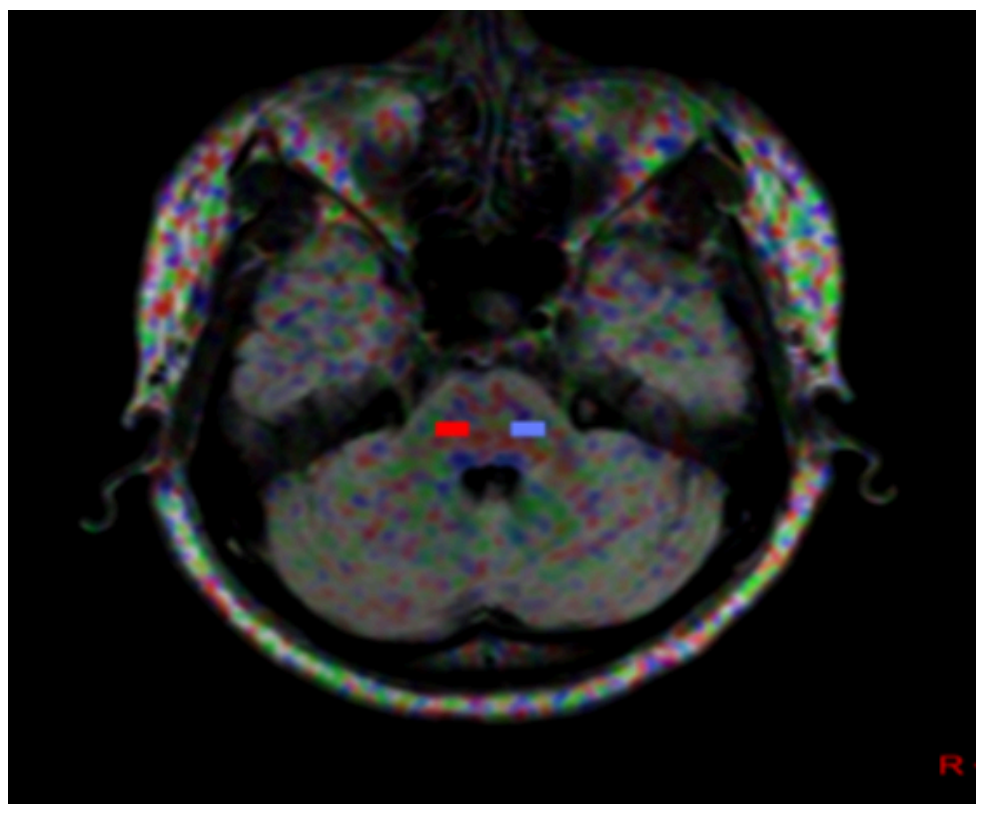


medRxiv preprint doi: https://doi.org/10.1101/2020.06.09.20126755; this version posted June 11, 2020. The copyright holder for this preprint (which was not certified by peer review) is the author/funder, who has granted medRxiv a license to display the preprint in perpetuity. It is made available under a CC-BY-ND 4.0 International license.

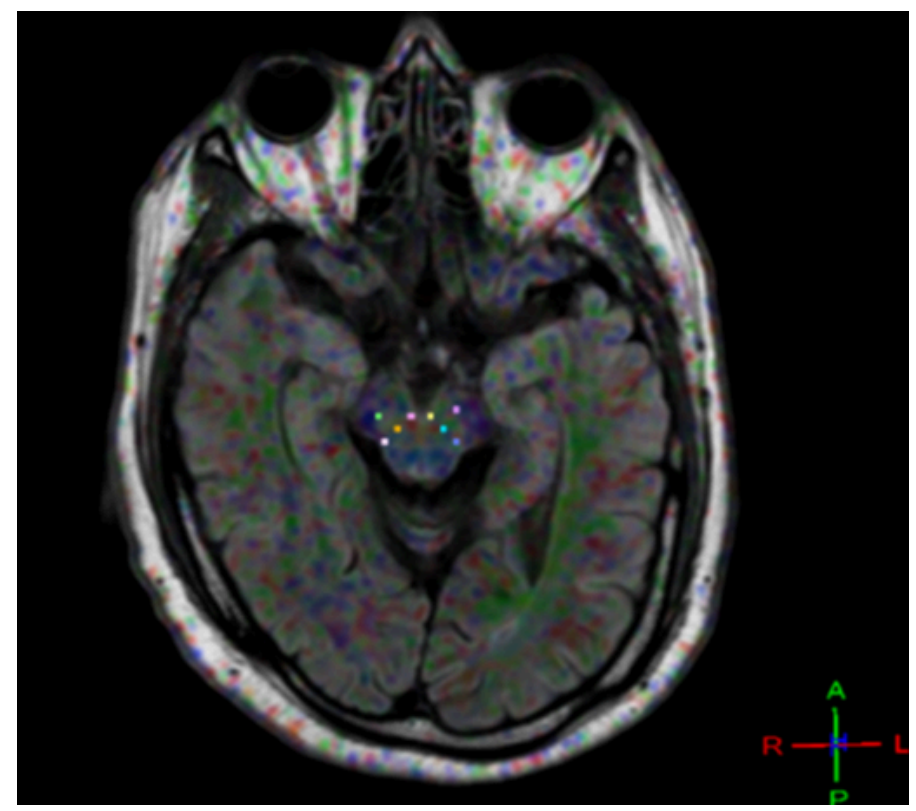


medRxiv preprint doi: https://doi.org/10.1101/2020.06.09.20126755; this version posted June 11, 2020. The copyright holder for this preprint (which was not certified by peer review) is the author/funder, who has granted medRxiv a license to display the preprint in perpetuity. It is made available under a CC-BY-ND 4.0 International license.

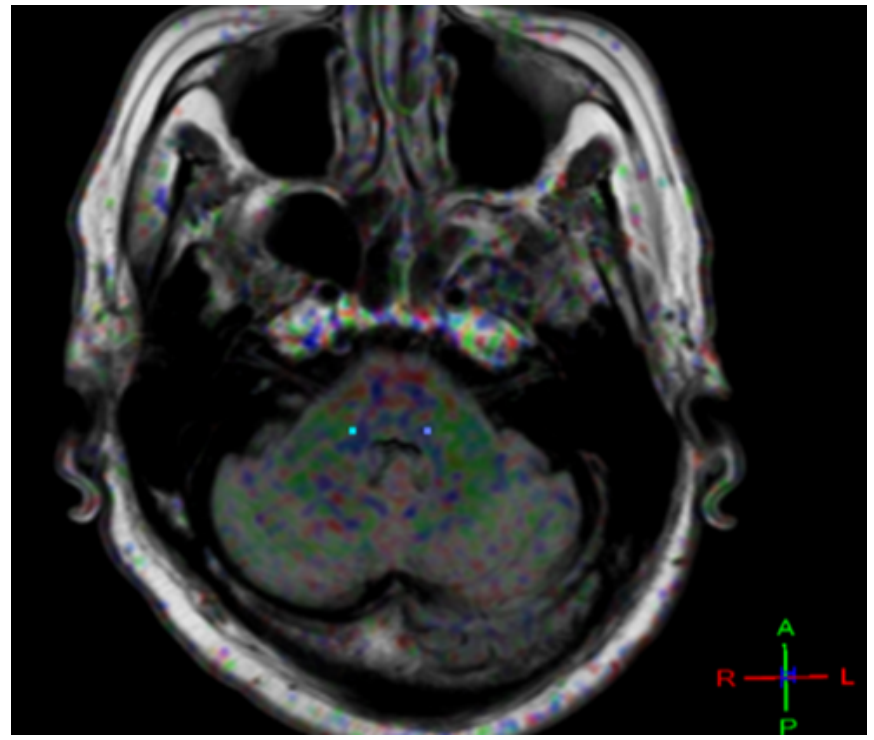


medRxiv preprint doi: https://doi.org/10.1101/2020.06.09.20126755; this version posted June 11, 2020. The copyright holder for this preprint (which was not certified by peer review) is the author/funder, who has granted medRxiv a license to display the preprint in perpetuity. It is made available under a CC-BY-ND 4.0 International license.

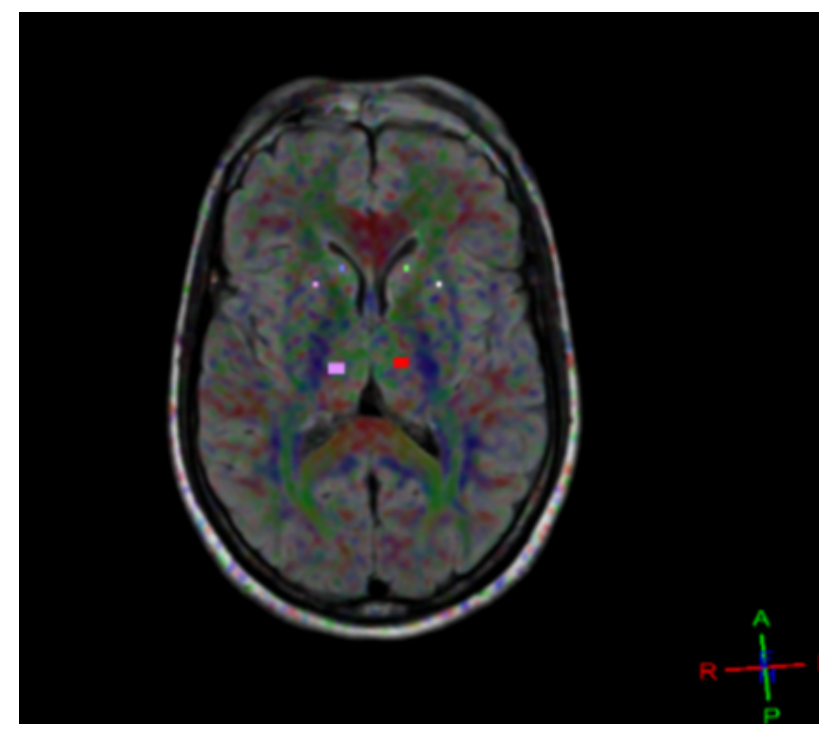

